\title{
Intra-Industry Effects of Delayed New Product Introductions
}

\author{
Sheng-Syan Chen* \\ Department of Finance, College of Management, National Taiwan University \\ Taipei, Taiwan \\ fnschen@management.ntu.edu.tw.
}

\section{Tsai-Yen Chung}

Department of Accounting, College of Management, Yuan Ze University

Taoyuan, Taiwan

tychung@saturn.yzu.edu.tw.

\section{Kim Wai Ho}

Division of Banking and Finance, Nanyang Business School

Nanyang Technological University, Singapore

akwho@ntu.edu.sg.

\section{Cheng-Few Lee}

Department of Finance, School of Business, Rutgers University, New Brunswick NJ 08903, USA, and Department of Finance, College of Management

Da-Yeh University, Chang-Hua, Taiwan

lee@rbs.rutgers.edu.

We find that for a sample of 324 announcements of delayed new product introductions in 52 industries from 1989 to 1997, the rivals overall experience significantly negative share price response. The results suggest that, for the sample as a whole, the information-signaling effect dominates the competitive effect. We further classify the rivals' share price response by industry and find that about $60 \%$ of industries have negative response. We also find that a product delay conveys more negative information about the competitors in those industries that are more likely to have product delays. Finally, we show that rivals' share price response is significantly positively related to the announcement effect on the product delay firm, the degree of industry competition, and the industry growth opportunities, and is significantly

\footnotetext{
*Corresponding author.
} 
negatively related to the degree of relatedness of the announcing firm to the industry, and to the level of the announcing firm's free cash flow relative to that of its competitors.

Keywords: Product delays; intra-industry effects; information-signaling effect; competitive effect.

\section{Introduction}

Previous studies show that firms that delay new product introductions might experience higher development and manufacturing costs, a loss of market share and revenues, and higher intangible costs, such as a loss of goodwill among customers and negative impressions about management's competence (see, e.g., Biggadike 1976; Ohmae, 1985; Robinson and Fornell, 1985; Urban et al., 1986; Davis, 1989; and Nevens et al., 1990). Hendricks and Singhal (1997) show that the market values of these firms generally decrease by about $5 \%$ upon the delay announcements. Their results indicate that the costs of delays in new product introductions outweigh any potential benefits. ${ }^{1}$

The results of the above studies are insightful, but they do not tell us how the other firms in the industry are economically affected by delays in new product introductions. ${ }^{2}$ In this paper, we extend the literature by examining how such delays by a firm could affect the stock prices of its competitors. Although Hendricks and Singhal (1997) did suggest that it would be useful to study the intra-industry effects of product delays, this research issue has so far escaped the attention of researchers. Anecdotal evidence suggests that stock prices of rival firms could be affected differently by delay announcements. For example, when Centocor announced its delay in the introduction of its flagship septic-shock drug Centoxin after it was told that the Food and Drug Administration (FDA) lacked sufficient data to approve Centoxin, the share price of Centocor lost $41 \%$ within one day, and its competitors Amgen, Genzyme and Xoma - all registered declines in share prices (Wall

\footnotetext{
${ }^{1}$ The potential benefits of delaying new product introductions include the ability to incorporate newer technologies in the product, economy of scale in introducing a number of products simultaneously, and the avoidance of negative publicity about a new product (Hendricks and Singhal, 1997).

${ }^{2}$ Previous studies document that announcements by a firm could contain signals about firms in the corresponding industry. See, e.g., Foster (1981), Eckbo (1983), Baginski (1987), Slovin et al. (1991), Lang and Stulz (1992), Slovin et al. (1992), Szewczyk (1992), Firth (1996), Eckel et al. (1997), Chen et al. (2005), and Chen et al. (2006). However, other studies, such as Aharony and Swary (1983), Hertzel (1991) and Ahmed et al. (2002), show that such announcements could convey no information about the industry.
} 
Street Journal, April 16, 1992). In contrast, when Advanced Micro Devices announced that it would delay the release of its K5 chip, a prospective competitor to Intel's Pentium processors, Intel shares surged about 3\% (Wall Street Journal, April 12, 1995). The main objective of our paper is to examine the factors that could potentially explain these differential stock price effects of delay announcements on industry rivals.

The economic impact of a delay in new product introduction by a firm on its rivals depends upon the interaction of two effects: the informationsignaling effect and the competitive effect. The information-signaling effect suggests that delays in new product introductions by a firm would result in negative spillover effects on other firms in the same industry. A delayed new product introduction could indicate certain industry-wide problem. For example, in the Centocor case, the stock market could infer from its announcement that other firms in the industry might also experience a delay in obtaining FDA approval for their products. Another reason for the negative informationsignaling effect is that the stock market might have anticipated the introductions of certain new products that could lead to accelerated industry-wide market growth and expansion, which could also benefit industry rivals. ${ }^{3} \mathrm{~A}$ delay in the new product introduction could reduce the potential for such market expansion because customers' needs might have changed by the time a delayed product is introduced to the market (Hendricks and Singhal, 1997). Thus, to the extent that the market values of industry firms have already incorporated the positive market expansion effect of an anticipated new product introduction, a delay announcement could trigger a downward revision of stock prices for these firms.

A delayed new product introduction by a firm might have positive effects on its rival firms. Hendricks and Singhal (1997) suggest that firms that delay new product introductions could be at a competitive disadvantage and could lag behind its competitors on the learning curve. Customers might also be diverted to buy the competitors' products because customers might not be willing to wait for the new product. Thus, the competitive intra-industry effect implies that industry rivals could experience positive economic benefits at the expense of the announcing firm. For example, in the microprocessor case above, Intel could continue to benefit from sales of its Pentium chips because of the delay in the introduction of a rival product.

\footnotetext{
${ }^{3}$ Mahajan et al. (1993) use the case of the instant camera market to show that the market expansion effect of a new product introduction can be significant. The introduction of the instant cameras by Eastman Kodak Company expanded the market by 37\%, which also benefited its rival Polaroid Corporation.
} 
For a sample of 324 announcements of delayed new product introductions in 52 industries from 1989 to 1997, we show that the announcing firms experience significantly negative wealth effects, which are consistent with the findings in Hendricks and Singhal (1997). We also find that, on average, rival firms experience significantly negative share price response, which suggests that, for the sample as a whole, the information-signaling effect dominates the competitive effect. We further classify the rivals' share price response by industry and find that about $60 \%$ of the industries have negative response. In particular, rivals in pharmaceuticals preparations, industrial organic chemicals, and air transport industries experience the most statistically significant unfavorable share price response. We also show that a product delay conveys more negative information about the competitors in those industries that have more product delays. This finding suggests that these industries might experience certain industry-wide problems in new product introductions.

In our cross-sectional regression analysis of the intra-industry effects of delay announcements, we find that rivals' share price response is significantly positively related to the announcing firm's abnormal return. The evidence suggests that rivals' share prices are more adversely affected when the wealth effect on the announcing firm is more negative. This finding further supports that the information-signaling effect dominates the competitive effect in our sample. Our result is also consistent with the findings in previous studies on other corporate events that intra-industry effects are more pronounced when the share price of the announcing firm is affected to a greater degree (see Hertzel, 1991; Firth, 1996; Chen et al., 2005; Chen et al., 2006).

Next, we find that the degree of relatedness of the announcing firm to the industry has a significantly negative impact on rivals' share price response. This finding suggests that the negative information associated with a product delay is more likely to be transmitted throughout the industry when the announcing firm's performance is more closely linked to its rivals. Previous studies, such as Lang and Stulz (1992) and Firth (1996), also find that intraindustry effects are more pronounced when the announcing firm is closely related to its rival firms.

We also find that rivals' share price response is significantly negatively related to the level of the announcing firm's free cash flow relative to that of its rivals. Firms that delay new product introductions typically experience higher development and manufacturing costs (see, e.g., Clark and Fujimoto, 1991), and hence, require more funds to meet these costs. If these firms have low level of internally generated funds, they might not be able to successfully 
introduce the product to the market. Industry rivals would then gain a greater competitive advantage at the expense of such announcing firms, and consequently, would experience a more positive economic impact.

Our results also show that rivals' share price response is significantly positively related to the degree of industry competition and the industry growth opportunities. Hendricks and Singhal (1997) suggest that firms that delay the introduction of new products in a highly competitive industry or in a fast growing industry are more likely to experience lost sales, lower profits, and a loss of competitive advantage. Our findings support that industry rivals in these industries gain competitive advantage at the expense of the announcing firms, and these gains are reflected in higher stock price response.

Finally, we find that the announcing firm's size and financial leverage relative to those of its rivals, the technological opportunities in the industry, and information on the expected length of delay are not significant in explaining the rivals' share price response. The results suggest that these factors are relatively unimportant in assessing the valuation effects of delayed new product introductions on industry rivals.

The remainder of the paper proceeds as follows. Section 2 discusses the hypotheses. Section 3 describes the sample selection procedure and the data. Section 4 presents the methodology used to test the hypotheses. Section 5 reports and discusses the empirical results. Section 6 concludes the paper.

\section{Hypotheses}

In this section, we discuss the hypotheses relating to various factors that could potentially influence the information-signaling and competitive effects of delays in new product introductions. These factors include the stock price response for the announcing firm; the degree of relatedness of the announcing firm to the industry; the announcing firm's size, free cash flow, and financial leverage relative to those of its rivals; the competitiveness, growth and technological opportunities in the industry; and the information on the expected length of delay.

\subsection{Stock price response for the announcing firm}

The intra-industry effects of corporate announcements might depend upon the magnitude of the announcing firm's signal (Hertzel, 1991; Zantout and Tsetsekos, 1994; Firth, 1996; Erwin and Miller, 1998; Akhigbe and Martin, 2000; Chen et al., 2005; Chen et al., 2006). Product delays that convey little or no information about the announcing firm are not likely to convey 
information about the industry in which the firm operates. On the other hand, product delays that are accompanied by significant share price reactions for the announcing firms are more likely to have significant intraindustry effects. The information-signaling effect suggests that when an announcing firm experiences a less favorable share price response, its rivals would experience a more pronounced negative share price response, and hence, the announcement effects on the announcing firms and their rivals should be positively related. On the other hand, the competitive effect would suggest a negative relation, because rivals are expected to benefit more in terms of stock price response when the announcing firm experiences a more negative stock price effect.

\subsection{Degree of relatedness}

Previous studies show that the intra-industry effects of corporate events might also depend upon the degree of relatedness of the announcing firm to the industry (Lang and Stulz, 1992; Firth, 1996; Akhigbe et al., 1997; Erwin and Miller, 1998; and Akhigbe and Martin, 2000). Product delays of firms whose performance is more closely related to other firms in the industry are expected to elicit more pronounced intra-industry information-signaling effects. The negative prospects of the firm that announces product delay are more likely to be transmitted throughout the industry when the firm's performance is closely linked to its competitors. Thus, rivals are expected to experience poorer share price response associated with delay announcements when the announcer is closely related to the industry.

\subsection{Relative firm size}

Large firms are more likely to be perceived as leaders in the industry (Akhigbe et al., 1997), and their announcements are more likely to represent industry-wide factors and to impart information transfer (Hertzel, 1991; Zantout and Tsetsekos, 1994; Firth, 1996; and Song and Walkling, 2000). Further, information production and dissemination are a positive function of firm size (Atiase, 1985; Chaney et al., 1991; and Slovin et al., 1991), and hence, the expected change in firm value for rivals induced by public announcements of product delays should be more pronounced for small rivals. Thus, product delays of large announcing firms are expected to induce a more negative information-signaling effect on small rivals.

Hendricks and Singhal (1997) suggest that firm size is a proxy for diversification. They find that the stock price effects of delay announcements by large and more diversified firms are less negative. They argue that such 
firms operates in many different products and a delay in one product line might not have a significant impact on the firm's profitability. Thus, delay announcements by larger firms might not elicit significant competitive effects on their smaller rivals. On the other hand, small announcing firms are less diversified and more vulnerable, and their larger rivals could gain more competitive advantage.

Thus, both the information-signaling and competitive effects suggest a negative relation between rivals' stock price response and the announcing firm's size relative to that of the rivals.

\subsection{Relative free cash flow}

The availability of internal funds has an impact on corporate investment (Fazzari et al., 1988; Hoshi et al., 1991). Bolton and Scharfstein (1990) suggest that an important determinant of product-market success is the degree to which firms can finance investment with internally generated funds. Low free-cash-flow firms have less ability to invest and less flexibility to respond to changes in market conditions. Such firms might not have sufficient funds to finance the higher development and manufacturing costs associated with delays in new product introductions, and hence, might not be able to successfully introduce the new products to the market. Thus, rivals should experience a more positive competitive effect when product delay firms have low free cash flow relative to that of their rivals.

\subsection{Relative financial leverage}

Financial leverage might limit a firm's ability to make investments to respond to competitive challenges (Stulz, 1990). A firm's debt overhang might also prevent it from raising funds to finance positive net present value projects (Myers, 1977; Phillips, 1995; Lang et al., 1996; and Kovenock and Phillips, 1997). Highly leveraged firms that experience delays in new product introductions are expected to have greater difficulty in raising external funds to finance their product development. Thus, industry rivals are expected to experience a more positive competitive effect when product delay firms are more leveraged than their competitors.

\subsection{Degree of industry competition}

Hendricks and Singhal (1997) suggest that in a highly competitive industry, customers are more likely to have a wider choice of competing products from different firms. Also, in such industries, the ability to introduce 
new products faster and on time is an important source of differentiation and competitive advantage. Hendricks and Singhal find that firms in highly competitive industries have more negative stock price effects associated with delays in new product introductions than do firms in less competitive industries. Their results support that firms that delay the introduction of new products in a highly competitive industry are more likely to experience lost sales, lower profits, and a loss of competitive advantage. Their rivals should, therefore, gain more competitive advantage and experience more favorable share price response.

\subsection{Growth opportunities in the industry}

Hendricks and Singhal (1997) argue that delaying the introduction of new products in a fast growing industry is more likely to result in a significant loss of market share for the announcing firm. They suggest that, in these industries, there tends to be new customers entering the market, and these customers are less likely to wait for a firm's product if the product introduction is delayed. In addition, the probability of rival firms introducing competing products is higher in high growth industries. Thus, rivals in high growth industries are expected to experience better wealth effects in response to a delay announcement by another firm in the same industry.

\subsection{Industry technological opportunities}

Firms in more technologically based industries have greater technology opportunities and require new product innovations to stay alive (Chaney et al., 1991). Also, investors typically expect new product announcements by firms in industries with greater technology opportunities (Kelm et al., 1995). If they fail to perform up to the market's expectation, such as being late in new product introductions, the market might be disappointed, and investors might cast doubts on these firms' ability to compete. Customers might also have negative impression on the product quality of these firms and might switch to other competing products. Thus, when firms in industries that have greater technology opportunities delay the introductions of new products, their rivals are expected to experience a more positive competitive effect and a better share price response.

\subsection{Information on the expected length of delay}

Hendricks and Singhal (1997) find some evidence that, among firms that announce delayed new product introductions, those that announce estimates 
for the length of delay fare better than those that provide no such estimates. They argue that, when the length of delay is not known, there exists more uncertainty regarding whether the product will ever be introduced and consequently, some customers might switch to a competitor's product. However, the rivals' share price response might depend upon whether the uncertainty about the new product is firm-specific or industry-wide. If the uncertainty is firm-specific and there are substitute products, firms that do not provide an estimate on the expected length of delay are more likely to experience a loss of market share and their rivals are expected to experience better share price response. On the other hand, the uncertainty might be due to industry-wide factors. For example, the uncertainty might arise from a lack of data for FDA to approve certain types of drugs in the pharmaceutical industry. In such cases, industry rival firms would also suffer as a result of the delay announcements.

\section{Sample Selection}

We collect a sample of initial announcements of delayed new product introductions by firms listed on the New York Stock Exchange (NYSE), the American Stock Exchange (AMEX) or the NASDAQ exchange from the UMI's Wall Street Journal (WSJ) Ondisc database. The words and phrases and their synonyms commonly used to describe delayed new product introductions are selected as keys for a database search routine. Examples are "product introduction", "delay", "postpone" and "move" along with other pertinent words and phrases (as in Hendricks and Singhal, 1997). The sample period is from January 1989 to December 1997.

We exclude the announcements if there is no rival firm in the announcing firm's industry as defined by the primary four-digit Standard Industrial Classification (SIC) code in Compustat (as in Lang and Stulz, 1992). ${ }^{4} \mathrm{We}$ also exclude the announcing firms or their rivals if they do not have data available from the Center for Research in Securities Prices (CRSP) returns files. Our final sample comprises 324 new product delay announcements by 200 different firms in 52 industries.

Table 1 provides the sample distribution by year of announcement and by industries. There is no concentration of announcements in any particular year or particular period. The announcements mainly come from five

\footnotetext{
${ }^{4}$ Guenther and Rosman (1994), and Kahle and Walkling (1996) suggest that the CRSP SIC codes are not very representative of the industries in which the firms actually operate, leading to less precise inferences. Compustat SIC codes appear to be more reliable.
} 
Table 1. Distribution of delayed new product introductions by year and by industry.

\begin{tabular}{|c|c|c|c|c|}
\hline Year & ber of Announcem & lents & & $\%$ of Sample \\
\hline \multicolumn{5}{|c|}{ Panel A. Sample distribution by year } \\
\hline 1989 & 15 & & & 4.6 \\
\hline 1990 & 26 & & & 8.0 \\
\hline 1991 & 36 & & & 11.1 \\
\hline 1992 & 54 & & & 16.7 \\
\hline 1993 & 28 & & & 8.6 \\
\hline 1994 & 50 & & & 15.4 \\
\hline 1995 & 45 & & & 13.9 \\
\hline 1996 & 29 & & & 9.0 \\
\hline 1997 & 41 & & & 12.7 \\
\hline Total & 324 & & & 100.0 \\
\hline Industry & $\begin{array}{c}\text { Number of } \\
\text { Announcements }\end{array}$ & $\begin{array}{c}\% \text { of } \\
\text { Sample }\end{array}$ & $\begin{array}{l}\text { Number of } \\
\text { Firms }\end{array}$ & $\begin{array}{l}\text { Announcements } \\
\text { per Firm }\end{array}$ \\
\hline \multicolumn{5}{|c|}{ Panel B. Sample distribution by industry } \\
\hline $\begin{array}{l}\text { Agriculture production-crops } \\
(0100)\end{array}$ & 2 & 0.6 & 2 & 1.0 \\
\hline $\begin{array}{l}\text { Womens, misses, jrs outerwear } \\
\text { (2330) }\end{array}$ & 1 & 0.3 & 1 & 1.0 \\
\hline $\begin{array}{l}\text { Newspaper: pubg, pubg \& } \\
\text { print (2711) }\end{array}$ & 1 & 0.3 & 1 & 1.0 \\
\hline $\begin{array}{l}\text { Periodical: pubg, pubg \& print } \\
\quad(2721)\end{array}$ & 3 & 0.9 & 1 & 3.0 \\
\hline $\begin{array}{l}\text { Chemicals \& allied products } \\
\text { (2800) }\end{array}$ & 2 & 0.6 & 2 & 1.0 \\
\hline $\begin{array}{l}\text { Medicinal chems, botanicl pds } \\
\quad(2833)\end{array}$ & 1 & 0.3 & 1 & 1.0 \\
\hline $\begin{array}{l}\text { Pharmaceutical preparations } \\
\text { (2834) }\end{array}$ & 87 & 26.9 & 55 & 1.6 \\
\hline $\begin{array}{l}\text { In vitro, in vivo diagnostics } \\
(2835)\end{array}$ & 16 & 4.9 & 10 & 1.6 \\
\hline $\begin{array}{l}\text { Biological pds, ex diagnstics } \\
\text { (2836) }\end{array}$ & 29 & 9.0 & 21 & 1.4 \\
\hline $\begin{array}{l}\text { Soap, detergent, toilet preps } \\
\quad(2840)\end{array}$ & 4 & 1.2 & 1 & 4.0 \\
\hline $\begin{array}{l}\text { Industrial organic chemicals } \\
\text { (2860) }\end{array}$ & 3 & 0.9 & 1 & 3.0 \\
\hline Misc chemical products (2890) & 1 & 0.3 & 1 & 1.0 \\
\hline $\begin{array}{l}\text { Computer \& office equipment } \\
\text { (3570) }\end{array}$ & 19 & 5.9 & 3 & 6.3 \\
\hline Electronic computers (3571) & 15 & 4.6 & 7 & 2.1 \\
\hline $\begin{array}{l}\text { Computer storage devices } \\
\text { (3572) }\end{array}$ & 5 & 1.5 & 2 & 2.5 \\
\hline $\begin{array}{l}\text { Computer communication } \\
\text { equip (3576) }\end{array}$ & 1 & 0.3 & 1 & 1.0 \\
\hline
\end{tabular}


Table 1. (Continued)

Industry

\section{Number of $\%$ of}

Announcements Sample

\begin{tabular}{cc} 
Number of & $\begin{array}{c}\text { Announcements } \\
\text { per Firm }\end{array}$ \\
\hline
\end{tabular}

Office machines, nec (3579)

Electr, oth elec eq, ex cmp (3600)

Household audio \& video eq (3651)

Tele \& telegraph apparatus (3661)

Radio, tv broadcast, comm eq (3663)

Semiconductor, related device (3674)

Motor vehicles \& car bodies (3711)

Motor vehicle part, accessory (3714)

Aircraft (3721)

Aircraft engine, engine parts (3724)

Guided missiles \& space vehc (3760)

Srch, det, nav, guid, aero sys (3812)

Lab apparatus and furniture (3821)

Surgical, med instr, apparatus (3841)

Ortho, prosth, surg appl, suply (3842)

Electromedical apparatus (3845)

Photographic equip \& supply (3861)

Games, toys, chld veh, ex dolls (3944)

Air transport, scheduled (4512)

Air courier services (4513)

Radiotelephone communication (4812)

Phone comm ex radiotelephone (4813)

Television broadcast station (4833)

Cable and other pay tv svcs (4841)

\begin{tabular}{|c|c|c|c|}
\hline 1 & 0.3 & 1 & 1.0 \\
\hline 2 & 0.6 & 2 & 1.0 \\
\hline 2 & 0.6 & 2 & 1.0 \\
\hline 2 & 0.6 & 2 & 1.0 \\
\hline 3 & 0.9 & 1 & 3.0 \\
\hline 11 & 3.4 & 5 & 2.2 \\
\hline 9 & 2.8 & 3 & 3.0 \\
\hline 1 & 0.3 & 1 & 1.0 \\
\hline 7 & 2.2 & 2 & 3.5 \\
\hline 2 & 0.6 & 1 & 2.0 \\
\hline 1 & 0.3 & 1 & 1.0 \\
\hline 1 & 0.3 & 1 & 1.0 \\
\hline 1 & 0.3 & 1 & 1.0 \\
\hline 9 & 2.8 & 7 & 1.3 \\
\hline 8 & 2.5 & 6 & 1.3 \\
\hline 19 & 5.9 & 14 & 1.4 \\
\hline 1 & 0.3 & 1 & 1.0 \\
\hline 1 & 0.3 & 1 & 1.0 \\
\hline 7 & 2.2 & 7 & 1.0 \\
\hline 2 & 0.6 & 1 & 2.0 \\
\hline 1 & 0.3 & 1 & 1.0 \\
\hline 6 & 1.9 & 5 & 1.2 \\
\hline 1 & 0.3 & 1 & 1.0 \\
\hline 2 & 0.6 & 1 & 2.0 \\
\hline
\end{tabular}


Table 1. (Continued)

\begin{tabular}{|c|c|c|c|c|}
\hline Industry & $\begin{array}{c}\text { Number of } \\
\text { Announcements }\end{array}$ & $\begin{array}{c}\% \text { of } \\
\text { Sample }\end{array}$ & $\begin{array}{l}\text { Number of } \\
\text { Firms }\end{array}$ & $\begin{array}{l}\text { Announcements } \\
\text { per Firm }\end{array}$ \\
\hline Eating places (5812) & 1 & 0.3 & 1 & 1.0 \\
\hline Advertising (7310) & 1 & 0.3 & 1 & 1.0 \\
\hline $\begin{array}{l}\text { Credit reporting agencies } \\
\quad(7320)\end{array}$ & 1 & 0.3 & 1 & 1.0 \\
\hline Help supply services (7363) & 1 & 0.3 & 1 & 1.0 \\
\hline $\begin{array}{l}\text { Cmp programming, data } \\
\text { process }(7370)\end{array}$ & 1 & 0.3 & 1 & 1.0 \\
\hline Prepackaged software (7372) & 18 & 5.6 & 10 & 1.8 \\
\hline Misc business services (7380) & 4 & 1.2 & 1 & 4.0 \\
\hline $\begin{array}{l}\text { Auto repair, services, parking } \\
\quad(7500)\end{array}$ & 1 & 0.3 & 1 & 1.0 \\
\hline $\begin{array}{l}\text { Motion pic, videotape prodtn } \\
\quad(7812)\end{array}$ & 3 & 0.9 & 2 & 1.5 \\
\hline $\begin{array}{l}\text { Motion pict, videotape distr } \\
(7822)\end{array}$ & 1 & 0.3 & 1 & 1.0 \\
\hline Medical laboratories (8071) & 1 & 0.3 & 1 & 1.0 \\
\hline $\begin{array}{l}\text { Account, audit, bookkeep svcs } \\
\quad(8721)\end{array}$ & 1 & 0.3 & 1 & 1.0 \\
\hline Total & 324 & 100.0 & 200 & 1.6 \\
\hline
\end{tabular}

Note: This table summarizes the sample distribution of new product delay announcements by firms listed on the New York Stock Exchange (NYSE), the American Stock Exchange (AMEX) or the NASDAQ exchange from 1989 to 1997. The sample is collected from the Wall Street Journal. There are 324 announcements by 200 different firms in 52 industries. The industries are based on the primary four-digit SIC code in Compustat.

industries: pharmaceutical preparations (2834), biological products (2836), computer and office equipment (3570), electromedical apparatus (3845) and prepackaged software (7372) industries. These five industries constitute about $53 \%$ of the total sample, with pharmaceutical preparations (2834) having the highest number of announcements (about $27 \%$ of the total sample). The computer and office equipment industry (3570) has the highest announcement frequency per firm (about six announcements per firm in the sample period).

\section{Methodology}

In this section, we describe the event study methodology that we use to measure and test the stock price effects of delay announcements. We then describe how we measure proxy variables for the cross-sectional factors and present our regression models. 


\subsection{Event study methodology}

We use event-study methodology to examine stock-price response to announcements of delays in new product introductions. We measure abnormal returns $\left(A R_{i t}\right)$ for each product delay firm $i$ on day $t$ as the difference between the actual return $\left(R_{i t}\right)$ and an expected return generated by the market model: ${ }^{5}$

$$
A R_{i t}=R_{i t}-\left(\hat{\alpha}_{i}+\hat{\beta}_{i} R_{m t}\right)
$$

where $\hat{\alpha}_{i}$ and $\hat{\beta}_{i}$ are the least squares estimates of firm $i$ 's market model parameters over the pre-event period beginning day -200 to day -60 relative to the initial announcement date, and $R_{m t}$ is the return on the CRSP value-weighted market index over day $t$. We define the initial announcement date as day 0 . We compute abnormal returns for day -1 and day 0 , and cumulative abnormal returns over the period $(-59,-2),(-1,0)$, and $(1$, 30) by summing up the daily abnormal returns over the respective periods. The two-day period $(-1,0)$ captures the price reaction to the delay announcement, while the earlier period $(-59,-2)$ captures anticipation of the information and the later period $(1,30)$ captures early revisions to the initial reaction to the delay announcement.

We also measure the corresponding abnormal returns and cumulative abnormal returns for industry competitors in the same four-digit SIC code as the announcing firm. However, as the industry competitors for each announcing firm have a common event date, there is a potential cross-sectional correlation of returns problem leading to biased statistical tests of significance (see Szewczyk, 1992 and Firth, 1996). To overcome this problem, we group the industry competitors into equally-weighted portfolios, and then calculate the competitors' abnormal returns and cumulative abnormal returns using industry-grouped portfolio returns. ${ }^{6}$ We conduct significance tests using the $Z$-statistic, as described in Dodd and Warner (1983), and the Wilcoxon signed-rank test.

\footnotetext{
${ }^{5}$ The market model has been widely used in event studies (see, e.g., Woolridge and Snow, 1990; Hendricks and Singhal, 1997; Kabir et al., 1997; Capron and Pistre, 2002; Seth et al., 2002; Shen and Cannella, 2002; and Nixon et al., 2004).

${ }^{6}$ Previous studies have used either the value-weighted or equally-weighted methods to form rival portfolios (see, e.g., Slovin et al., 1991; Lang and Stulz, 1992; and Szewczyk, 1992). Lang and Stulz (1992) find little difference between the results based on the equallyweighted or the value-weighted portfolios. Our conclusions in this study remain unchanged when the value-weighted method is used.
} 


\subsection{Measuring proxy variables}

We collect data on the proxies for the cross-sectional factors from the CRSP and Compustat files and WSJ news content. We measure the announcement effect on the announcing firm (ACAR) by its two-day $(-1,0)$ announcementperiod abnormal return (as in Firth, 1996; Akhigbe et al., 1997). We use the correlation of stock returns between the announcer and its competitors for the year preceding the announcement (CORR) as a proxy for the degree of relatedness of the announcing firm to the industry (as in Lang and Stulz, 1992; Firth, 1996).

We measure the relative firm size variable by the announcer's sales divided by the median sales of the rivals for the fiscal year preceding the announcement. ${ }^{7}$ We then construct a dummy variable (SIZE) that takes a value of one if the relative firm size variable is greater than one, and zero otherwise (as in Akhigbe et al., 1997; and Akhigbe and Martin, 2000). We measure relative free cash flow by the announcer's cash flow ratio divided by the median cash flow ratio of the rivals, where cash flow ratio is defined as operating income before depreciation minus interest expense, taxes, preferred dividends, and common dividends, divided by the book value of total assets, for the fiscal year preceding the announcement (as in Lehn and Poulsen, 1989; Lang et al., 1991). We then define a dummy variable (FCF) that takes a value of one if relative free cash flow is greater than one, and zero otherwise. We measure relative financial leverage by the announcer's debt ratio divided by the median debt ratio of the rivals, where debt ratio is defined as the book value of long-term debt to the book value of total assets for the fiscal year prior to the announcement (as in Lang and Stulz, 1992). ${ }^{8}$ We then construct a dummy variable (LEV) that takes a value of one if relative financial leverage is greater than one, and zero otherwise. ${ }^{9}$

We use the Herfindahl index (HI) as a proxy for the degree of industry competition, where the Herfindahl index equals the sum of the squared fraction of industry sales by all firms in the industry for the fiscal year prior to the announcement (as in Lang and Stulz, 1992; Hendricks and Singhal, 1997; Song and Walkling, 2000). ${ }^{10}$ Although this index is a measure of industry

\footnotetext{
${ }^{7}$ Our results are qualitatively similar if we measure firm size by the market value of equity or the book value of total assets.

${ }^{8}$ We obtain similar results if we define debt ratio as the book value of total debt divided by the book value of total assets.

${ }^{9}$ Our results are qualitatively similar if we use continuous variables for relative firm size, free cash flow, and leverage, after removing outliers.

${ }^{10}$ Similar results hold if we compute the Herfindahl index using all firms in the industry, excluding the announcer.
} 
concentration, it has been widely used as a proxy for competitiveness because the degree of concentration and the degree of competition are generally inversely related.

We measure industry growth opportunities (GROWTH) by the threeyear average annual growth rates in sales prior to the delayed announcement (as in Hendricks and Singhal, 1997). ${ }^{11}$ We use industry R\&D intensity (RDI) as a proxy for industry technological opportunities (as in Comanor, 1967; and Kelm et al., 1995). We define industry R\&D intensity as R\&D expenditures by all firms in the four-digit SIC industry divided by industry net sales for the fiscal year prior to the announcement (as in Chan et al., 1990; Kelm et al., 1995; and Sundaram et al., 1996). Finally, we define a delay information dummy (TIME) that equals one if an estimate for the length of delay is given in the announcement and 0 otherwise (as in Hendricks and Singhal, 1997). ${ }^{12}$

Table 2 presents the information on the cross-sectional factors except for the announcing firms' two-day announcement-period abnormal returns (see Table 3) and the information on the expected length of delay (as described in Footnote 12). The number of observations varies because of data availability. The mean (median) returns correlation for our sample is $0.29(0.27)$. The announcing firms are, on average, larger than the median size of their industry rivals, and have higher levels of free cash flow and financial leverage than do their industry competitors. ${ }^{13}$ The mean (median) Herfindahl index is $0.23(0.18)$ and the average (median) industry growth rate is 0.20 (0.16). Finally, the industry R\&D intensity is 0.11 on average $(0.10$ at the median).

\footnotetext{
${ }^{11} \mathrm{We}$ also measure the median ratio of the market to book value of assets for all firms in an industry, where the market value of assets equals the book value of assets minus the book value of common equity plus the market value of common equity (as in Denis, 1994; Barclay and Smith, 1995). We then use the three-year average of this ratio prior to the announcement as an alternative proxy for industry growth opportunities (as in Lang et al., 1989 and 1991; and Chen and Ho, 1997). We obtain qualitatively similar results.

${ }^{12}$ Seventy-three out of 324 announcements in our sample provided an estimate on the length of delay, which ranged from 0.5 month to 84 months with an average (median) of 5.8 (3.0) months. Hendricks and Singhal (1997) also find that most firms in their sample did not provide estimates on the length of delay.

${ }^{13}$ In 252 announcements, the announcer's sales is larger than the median sales of the rivals. In 160 announcements, the announcer's cash flow ratio is higher than the median cash flow ratio of the rivals. In 173 announcements, the announcer's financial leverage is greater than the median financial leverage of the rivals.
} 
Table 2. Descriptive statistics for the explanatory variables.

\begin{tabular}{lcrrr}
\hline Variable & N & Mean & Median & $\begin{array}{r}\text { Standard } \\
\text { Deviation }\end{array}$ \\
\hline Returns correlation & 324 & 0.29 & 0.27 & 0.21 \\
Relative size & 324 & 150.29 & 7.32 & 359.28 \\
Relative free cash flow & 308 & 1.29 & 1.02 & 9.16 \\
Relative financial leverage & 321 & 10.46 & 1.14 & 55.80 \\
Herfindahl index & 324 & 0.23 & 0.18 & 0.20 \\
Industry growth rate & 324 & 0.20 & 0.16 & 0.18 \\
Industry R\&D intensity & 308 & 0.11 & 0.10 & 0.07 \\
\hline
\end{tabular}

Note: Returns correlation is measured by the correlation of stock returns between the announcer and its competitors for the year preceding the announcement. Relative size is proxied by the announcer's sales divided by the median sales of rivals preceding the announcement. Relative free cash flow is measured by the announcer's cash flow ratio divided by the median cash flow ratio of the rivals, where cash flow ratio is defined as operating income before depreciation minus interest expense, taxes, preferred dividends and common dividends, divided by the book value of total assets, for the fiscal year preceding the announcement. Relative financial leverage is measured by the announcer's debt ratio divided by the median debt ratio of the rivals, where debt ratio is defined as the book value of long-term debt to the book value of total assets for the fiscal year prior to the announcement. The Herfindahl index is the sum of the squared fraction of industry sales by all firms in the industry for the fiscal year prior to the announcement. The industry growth rate is measured by the three-year average annual growth rates in sales prior to the announcement. Industry $R \& D$ intensity is defined as $R \& D$ expenditures by all firms in the industry divided by industry net sales for the fiscal year prior to the announcement. The number of observations varies because of data availability.

\subsection{Cross-sectional regression models}

We use the following regression models to test our hypotheses. The dependent variable RCAR in the models is two-day $(-1,0)$ announcement-period abnormal returns of industry rival portfolios.

$$
\begin{aligned}
\mathrm{RCAR}= & \beta_{0}+\beta_{1} \mathrm{ACAR}+\text { error } \\
\operatorname{RCAR}= & \beta_{0}+\beta_{1} \mathrm{ACAR}+\beta_{2} \mathrm{CORR} \\
& +\beta_{3} \mathrm{SIZE}+\beta_{4} \mathrm{FCF}+\beta_{5} \mathrm{LEV}+\beta_{6} \mathrm{HI} \\
& +\beta_{7} \mathrm{GROWTH}+\beta_{8} \mathrm{RDI}+\beta_{9} \mathrm{TIME}+\text { error } \\
\mathrm{RCAR}= & \beta_{0}+\beta_{1} \mathrm{ACAR}+\beta_{2} \mathrm{CORR} \\
& +\beta_{3} \mathrm{SIZE}+\beta_{4} \mathrm{FCF}+\beta_{5} \mathrm{LEV}+\beta_{6} \mathrm{HI} \\
& +\beta_{7} \mathrm{GROWTH}+\beta_{8} \mathrm{RDI} \\
& +\beta_{9} \mathrm{TIME}+\beta_{10} \mathrm{PLC}+\text { error }
\end{aligned}
$$




$$
\begin{aligned}
\mathrm{RCAR}= & \beta_{0}+\beta_{1} \mathrm{ACAR}+\beta_{2} \mathrm{CORR} \\
& +\beta_{3} \mathrm{SIZE}+\beta_{4} \mathrm{FCF}+\beta_{5} \mathrm{LEV}+\beta_{6} \mathrm{HI} \\
& +\beta_{7} \mathrm{GROWTH}+\beta_{8} \mathrm{RDI}+\beta_{9} \mathrm{TIME} \\
& +\beta_{10} \mathrm{PLC}+\beta_{11} \mathrm{CONTAM}+\text { error }
\end{aligned}
$$

Equation (2) includes ACAR only, and Equation (3) includes all the potential explanatory variables. In Equation (4), we add a product life cycle dummy (PLC) as a control variable. PLC equals one if the product involved in the delay is computer hardware or software, and zero otherwise. Hendricks and Singhal (1997) hypothesize that the economic impact for firms delaying the introduction of new products could be more negative for products with short life cycles, because the window of opportunity for introducing such products is small. Since the intra-industry effects might depend upon the magnitude of the announcing firm's signal, we also include PLC as a potentially influential variable. We follow Hendricks and Singhal by classifying computer hardware or software products as having short life cycles, and the rest of products as having long life cycles. ${ }^{14}$ In Equation (5), we add a contamination dummy (CONTAM) to control for contaminated events, where CONTAM equals one if there are simultaneous announcements, and zero otherwise. ${ }^{15}$ To test the significance of the coefficients in the models, we compute $t$-values using heteroskedasticity-consistent standard errors if tests reject homoskedasticity at the $10 \%$ significance level (White, 1980).

\section{Empirical Results}

In this section, we first present the results from the event study, and then the cross-sectional regression results.

\subsection{Event study results}

Table 3 shows that the announcing firms experience significantly negative abnormal returns for day before and the day of announcement. For the twoday $(-1,0)$ announcement-period, the product delay announcers experience an average loss of $11.40 \% .{ }^{16}$ These results are consistent with Hendricks and Singhal (1997) who find that delay announcements decrease the market value of the announcing firms by about $5.25 \%$. The larger negative wealth effect on the announcing firms in our sample may be explained by the fact that

\footnotetext{
${ }^{14}$ Fifty-nine products in our sample are classified as having short product life cycle.

${ }^{15}$ Sixty-eight observations had contemporaneous announcements.

${ }^{16}$ About $79 \%$ of the two-day $(-1,0)$ abnormal returns are negative.
} 
Table 3. Abnormal returns associated with new product delay announcements

\begin{tabular}{ccccc}
\hline $\begin{array}{c}\text { Period } \\
\text { Relative to the } \\
\text { Announcement }\end{array}$ & $\begin{array}{c}\text { Mean } \\
\text { Abnormal } \\
\text { Return (\%) }\end{array}$ & $z$-Statistic & $\begin{array}{c}\text { Median } \\
\text { Abnormal } \\
\text { Return (\%) }\end{array}$ & $\begin{array}{c}p \text {-value for the } \\
\text { Wilcoxon } \\
z \text {-Statistic }\end{array}$ \\
\hline $\begin{array}{c}\text { Panel A. Announcing firms } \\
{[-59,-2]}\end{array}$ & -2.01 & -1.81 & -1.80 & 0.27 \\
-1 & -9.56 & -45.61 & -2.95 & $<0.01$ \\
0 & -1.93 & -9.10 & -0.42 & 0.03 \\
{$[-1,0]$} & -11.40 & -38.53 & -4.06 & $<0.01$ \\
{$[1,30]$} & -1.19 & -1.77 & -0.67 & 0.29 \\
\hline Panel B. Industry rivals & & & 0.62 \\
{$[-59,-2]$} & 0.09 & 0.82 & 0.44 & 0.08 \\
-1 & -0.16 & -2.81 & -0.11 & 0.15 \\
0 & -0.12 & -1.38 & -0.11 & 0.03 \\
{$[-1,0]$} & -0.28 & -2.97 & -0.14 & 0.24 \\
{$[1,30]$} & -0.51 & -0.55 & -0.16 & \\
\hline
\end{tabular}

Note: The abnormal return is estimated using the standard market model procedure with parameters estimated for the period 200 days to 60 days before the announcement. The sample includes all new product delays between 1989 and 1997 of firms for which a primary four-digit SIC code is available from the Compustat data file (324 new product delays). A rival portfolio is an equally weighted portfolio of firms with the same primary four-digit SIC code for which returns are available from the CRSP files. Significance tests are conducted using the $z$-statistic described in Dodd and Warner (1983).

we examine delay announcements in more recent years (from 1989 to 1997, as compared to the sample period of 1984 to 1991 in Hendricks and Singhal, 1997). New products in recent years might be more innovative and valuable, and delay in their introductions might have larger negative consequences on the announcing firms. Similar to Hendricks and Singhal (1997), we also find some evidence of slight negative drift before and after the announcements.

Table 3 also presents the abnormal returns for rival portfolios. The evidence shows that for the two-day announcement-period, industry rivals experience an average value loss of $0.28 \%$, which is small, but statistically significant. ${ }^{17}$ There is no evidence of negative drift for the rivals before and

\footnotetext{
$\overline{{ }^{17} \text { Previous studies }}$ on intra-industry effects show that average announcement effects on rivals are typically small, but statistically significant. For instance, the average two-day announcement-period abnormal returns for rivals are $-0.16 \%$ for R\&D spending (Sundaram et al., 1996), $-0.15 \%$ for new product introductions (Chen et al., 2002), $-0.35 \%$ for bankruptcies (Lang and Stulz, 1992), 0.35\% for acquisition targets (Song and Walkling, 2000), and $-0.64 \%$ for common stock offerings (Szewczyk, 1992). The statistical significance could be due to the unusually low standard errors resulting from averaging the returns across a number of firms within each four-digit SIC code (Sundaram et al., 1996).
} 
after the delay announcements. Our results suggest that, on average, the negative information-signaling effect on industry rivals dominates the positive competitive effect.

To assess the economic significance of the abnormal returns, we calculate the average dollar change in market value of the announcing firms and their rivals. Using the two-day $(-1,0)$ announcement-period abnormal return and the firms' market value of equity for the fiscal year preceding the announcement, we find that, at 1989 prices, the average dollar loss to the announcing firms is $\$ 122$ million, ${ }^{18}$ and the average total dollar loss experienced by industry rivals corresponding to each new product announcement is $\$ 179$ million. ${ }^{19}$ Thus, the average dollar loss in market value of firms in an industry as a whole is $\$ 301$ million. At 1997 prices, the corresponding dollar losses to the announcers, their rivals, and to the industry as a whole, are $\$ 158$ million, $\$ 232$ million, and $\$ 390$ million respectively. These findings indicate significantly negative industry-wide effects that could result from delays in new product introductions.

We further classify the rival portfolios' two-day announcement-period abnormal returns by industry in Table 4 . If an industry has more than one product delay in our sample, we report the average of the industry portfolio abnormal returns across all product delays. We compute the $z$-statistics for each industry using the standardized rival portfolio abnormal return for each product delay. Thirty-one out of 52 (about 60\%) industries have negative average two-day announcement-period abnormal returns, which is significantly more than one would expect under the null hypothesis of no abnormal returns.

Twenty-one industries have more than two announcements. Of these industries, 13 (about 62\%) have negative average abnormal returns for rivals. Especially, the five industries with the highest number of announcements in our sample period (i.e., 2834, 2836, 3570, 3845 and 7372) all have negative abnormal returns for rivals. Further, rivals in pharmaceuticals preparations (2834), industrial organic chemicals (2860), and air transport (4512) industries experience the most statistically significantly unfavorable

\footnotetext{
${ }^{18}$ Hendricks and Singhal (1997) report that the average two-day $(-1,0)$ dollar loss to the firms that made delay announcements during the period 1984-1991 is about $\$ 119$ million at 1991 prices. At 1991 prices, the average dollar loss to the announcing firms in our sample is $\$ 134$ million, which is somewhat higher than that reported by Hendricks and Singhal.

${ }^{19}$ The dollar loss for rivals equals (rival portfolio $i$ 's announcement-period abnormal return $) \times($ mean market value of equity of firms in rival portfolio $i) \times($ number of firms in rival portfolio $i$ ).
} 
Table 4. Rivals' two-day announcement-period abnormal returns for each industry in the sample.

\begin{tabular}{|c|c|c|c|}
\hline Industry & $\begin{array}{c}\text { Number of } \\
\text { Announcements/ } \\
\text { Average Number of Firms } \\
\text { in the Rival Portfolio }\end{array}$ & $\begin{array}{l}\text { Mean } \\
\text { Abnormal } \\
\text { Return } \\
(\%)\end{array}$ & $z$-statistic \\
\hline $\begin{array}{l}\text { Agriculture production-crops } \\
\text { (0100) }\end{array}$ & $2 / 13$ & 0.27 & 0.03 \\
\hline $\begin{array}{l}\text { Womens, misses, jrs outerwear } \\
\text { (2330) }\end{array}$ & $1 / 22$ & -0.17 & -0.09 \\
\hline $\begin{array}{l}\text { Newspaper: pubg, pubg \& print } \\
\text { (2711) }\end{array}$ & $1 / 12$ & -0.19 & -0.25 \\
\hline $\begin{array}{l}\text { Periodical: pubg, pubg \& print } \\
\text { (2721) }\end{array}$ & $3 / 9$ & -1.45 & -1.42 \\
\hline Chemicals \& allied products (2800) & $2 / 8$ & -0.51 & -0.38 \\
\hline $\begin{array}{l}\text { Medicinal chems, botanicl pds } \\
\quad(2833)\end{array}$ & $1 / 6$ & -0.37 & -0.11 \\
\hline $\begin{array}{l}\text { Pharmaceutical preparations } \\
\text { (2834) }\end{array}$ & $87 / 109$ & -0.24 & -2.09 \\
\hline In vitro, in vivo diagnostics $(2835)$ & $16 / 41$ & -0.58 & -1.36 \\
\hline Biological pds, ex diagnstics (2836) & $29 / 46$ & -0.64 & -1.31 \\
\hline Soap, detergent, toilet preps (2840) & $4 / 4$ & 0.22 & 0.41 \\
\hline Industrial organic chemicals (2860) & $3 / 10$ & -1.80 & -2.48 \\
\hline Misc chemical products $(2890)$ & $1 / 11$ & -0.81 & -0.58 \\
\hline $\begin{array}{l}\text { Computer \& office equipment } \\
(3570)\end{array}$ & $19 / 3$ & -0.27 & -0.54 \\
\hline Electronic computers (3571) & $15 / 16$ & -0.31 & -0.63 \\
\hline Computer storage devices (3572) & $5 / 15$ & -0.05 & -0.14 \\
\hline $\begin{array}{l}\text { Computer communication equip } \\
\text { (3576) }\end{array}$ & $1 / 42$ & -0.10 & -0.07 \\
\hline Office machines, nec (3579) & $1 / 5$ & 3.21 & 1.18 \\
\hline Electr, oth elec eq, ex cmp (3600) & $2 / 3$ & 0.09 & 0.25 \\
\hline Household audio \& video eq (3651) & $2 / 14$ & -1.39 & -1.17 \\
\hline Tele \& telegraph apparatus (3661) & $2 / 65$ & 0.41 & 0.41 \\
\hline $\begin{array}{l}\text { Radio, tv broadcast, comm eq } \\
\quad(3663)\end{array}$ & $3 / 59$ & 0.75 & 1.04 \\
\hline $\begin{array}{l}\text { Semiconductor, related device } \\
\text { (3674) }\end{array}$ & $11 / 54$ & 0.04 & -0.07 \\
\hline Motor vehicles \& car bodies (3711) & $9 / 16$ & 0.14 & 0.32 \\
\hline $\begin{array}{l}\text { Motor vehicle part, accessory } \\
\text { (3714) }\end{array}$ & $1 / 35$ & -0.33 & -0.31 \\
\hline Aircraft (3721) & $7 / 3$ & -1.68 & -0.73 \\
\hline Aircraft engine, engine parts (3724) & $2 / 6$ & -0.23 & -0.11 \\
\hline $\begin{array}{l}\text { Guided missiles \& space vehc } \\
\quad(3760)\end{array}$ & $1 / 2$ & 0.19 & 0.11 \\
\hline Srch, det, nav, guid, aero sys (3812) & $1 / 14$ & -0.44 & -0.28 \\
\hline Lab apparatus and furniture (3821) & $1 / 4$ & 2.01 & 0.79 \\
\hline
\end{tabular}


Table 4. (Continued)

\begin{tabular}{|c|c|c|c|}
\hline Industry & $\begin{array}{c}\text { Number of } \\
\text { Announcements/ } \\
\text { Average Number of Firms } \\
\text { in the Rival Portfolio }\end{array}$ & $\begin{array}{l}\text { Mean } \\
\text { Abnormal } \\
\text { Return } \\
(\%)\end{array}$ & $z$-statistic \\
\hline $\begin{array}{l}\text { Surgical, med instr, apparatus } \\
\quad(3841)\end{array}$ & $9 / 34$ & 0.12 & 0.37 \\
\hline $\begin{array}{l}\text { Ortho, prosth, surg appl, suply } \\
\quad(3842)\end{array}$ & $8 / 20$ & -0.16 & -0.08 \\
\hline Electromedical apparatus (3845) & $19 / 63$ & -0.27 & -0.81 \\
\hline $\begin{array}{l}\text { Photographic equip \& supply } \\
\text { (3861) }\end{array}$ & $1 / 13$ & 1.22 & 0.59 \\
\hline $\begin{array}{l}\text { Games, toys, chld veh, ex dolls } \\
\text { (3944) }\end{array}$ & $1 / 13$ & -2.02 & -0.69 \\
\hline Air transport, scheduled (4512) & $7 / 22$ & -1.17 & -2.67 \\
\hline Air courier services (4513) & $2 / 3$ & -0.59 & -0.30 \\
\hline $\begin{array}{l}\text { Radiotelephone communication } \\
\quad(4812)\end{array}$ & $1 / 15$ & 0.90 & 0.52 \\
\hline $\begin{array}{l}\text { Phone comm ex radiotelephone } \\
\text { (4813) }\end{array}$ & $6 / 45$ & 0.14 & 0.44 \\
\hline Television broadcast station (4833) & $1 / 5$ & -0.72 & -0.39 \\
\hline Cable and other pay tv svcs (4841) & $2 / 14$ & 0.48 & 0.60 \\
\hline Eating places $(5812)$ & $1 / 48$ & 0.20 & 0.18 \\
\hline Advertising (7310) & $1 / 3$ & 0.94 & 0.21 \\
\hline Credit reporting agencies $(7320)$ & $1 / 2$ & 0.61 & 0.16 \\
\hline Help supply services (7363) & $1 / 15$ & -0.93 & -0.45 \\
\hline $\begin{array}{l}\text { Cmp programming, data process } \\
(7370)\end{array}$ & $1 / 25$ & -1.23 & -0.60 \\
\hline Prepackaged software (7372) & $18 / 107$ & -0.16 & -0.51 \\
\hline Misc business services (7380) & $4 / 4$ & 1.10 & 0.68 \\
\hline $\begin{array}{l}\text { Auto repair, services, parking } \\
\quad(7500)\end{array}$ & $1 / 3$ & -2.87 & -0.81 \\
\hline $\begin{array}{l}\text { Motion pic, videotape prodtn } \\
\quad(7812)\end{array}$ & $3 / 15$ & 0.08 & 0.12 \\
\hline Motion pict, videotape distr (7822) & $1 / 3$ & -2.67 & -0.45 \\
\hline Medical laboratories (8071) & $1 / 12$ & 2.87 & 0.80 \\
\hline $\begin{array}{l}\text { Account, audit, bookkeep svcs } \\
\text { (8721) }\end{array}$ & $1 / 5$ & -0.48 & -0.14 \\
\hline
\end{tabular}

Note: The sample includes all new product delays between 1989 and 1997 of firms for which a primary four-digit SIC code is available from the Compustat data file (324 new product delays). For each announcing firm, we form an equally weighted portfolio of rivals with the same four-digit SIC code for which returns are available from the CRSP files. For each industry, the mean abnormal return is the average of the rival portfolio market model residual computed for each product delay over the two-day $(-1,0)$ announcement period. The $z$-statistics are computed for each industry using the standardized rival portfolio abnormal return for each product delay. 
share price response. All of these three industries have more than two product delays in our sample. Thus, we observe that, for industries that experienced more than two product delays in our sample period, the competitors' abnormal return averaged across delay announcements is typically negative and is more likely to be significant. ${ }^{20}$ The results suggest that a product delay conveys more negative information about the competitors in the industries that have more frequent delay announcements.

\subsection{Cross-sectional regression results}

Table 5 presents cross-sectional analysis of the announcement-period abnormal returns of industry rival portfolios. The number of observations varies across regressions because of data availability.

Model 1 shows that industry rivals' share price response is significantly positively related to the announcement effect on the firm that announces a

Table 5. Regressions of rivals' two-day announcement-period abnormal returns.

\begin{tabular}{|c|c|c|c|c|c|c|}
\hline Variable & $\begin{array}{l}\text { Variable } \\
\text { Name }\end{array}$ & $\begin{array}{l}\text { Pred. } \\
\text { Sign }\end{array}$ & $\begin{array}{c}\text { Equation (2) } \\
\text { Model } 1\end{array}$ & $\begin{array}{c}\text { Equation (3) } \\
\quad \text { Model } 2\end{array}$ & $\begin{array}{c}\text { Equation (4) } \\
\text { Model } 3\end{array}$ & $\begin{array}{c}\text { Equation (5) } \\
\text { Model } 4\end{array}$ \\
\hline Intercept & $\beta_{0}$ & $?$ & $\begin{array}{c}-0.00097 \\
(-0.86)\end{array}$ & $\begin{array}{l}0.00881 \\
(2.26)^{* *}\end{array}$ & $\begin{array}{l}0.00881 \\
(2.26)^{* *}\end{array}$ & $\begin{array}{l}0.00880 \\
(2.25)^{* *}\end{array}$ \\
\hline $\begin{array}{l}\text { Announcer's } \\
\text { abnormal return }\end{array}$ & ACAR & \pm & $\begin{array}{c}0.01603 \\
(2.83)^{* * *}\end{array}$ & $\begin{array}{c}0.02592 \\
(3.72)^{* * *}\end{array}$ & $\begin{array}{c}0.02590 \\
(3.68)^{* * *}\end{array}$ & $\begin{array}{l}0.02597 \\
(3.68)^{* * *}\end{array}$ \\
\hline $\begin{array}{l}\text { Returns } \\
\text { correlation }\end{array}$ & CORR & $(-)$ & & $\begin{array}{l}-0.01727 \\
(-3.28)^{* * *}\end{array}$ & $\begin{array}{l}-0.01729 \\
(-3.23)^{* * *}\end{array}$ & $\begin{array}{l}-0.01752 \\
(-3.24)^{* * *}\end{array}$ \\
\hline $\begin{array}{l}\text { Relative firm } \\
\text { size }\end{array}$ & SIZE & $(-)$ & & $\begin{array}{l}-0.00085 \\
(-0.31)\end{array}$ & $\begin{array}{c}-0.00085 \\
(-0.31)\end{array}$ & $\begin{array}{c}-0.00090 \\
(-0.32)\end{array}$ \\
\hline $\begin{array}{l}\text { Relative free } \\
\text { cash flow }\end{array}$ & $\mathrm{FCF}$ & $(-)$ & & $\begin{array}{l}-0.00473 \\
(-2.30)^{* *}\end{array}$ & $\begin{array}{l}-0.00474 \\
(-2.27)^{* *}\end{array}$ & $\begin{array}{l}-0.00474 \\
(-2.27)^{* *}\end{array}$ \\
\hline $\begin{array}{l}\text { Relative financial } \\
\text { leverage }\end{array}$ & LEV & $(+)$ & & $\begin{array}{c}0.00103 \\
(0.50)\end{array}$ & $\begin{array}{c}0.00103 \\
(0.50)\end{array}$ & $\begin{array}{c}0.00104 \\
(0.51)\end{array}$ \\
\hline Herfindahl index & $\mathrm{HI}$ & $(-)$ & & $\begin{array}{l}-0.01165 \\
(-2.23)^{* *}\end{array}$ & $\begin{array}{l}-0.01164 \\
(-2.23)^{* *}\end{array}$ & $\begin{array}{l}-0.01186 \\
(-2.24)^{* *}\end{array}$ \\
\hline $\begin{array}{l}\text { Industry growth } \\
\text { rate }\end{array}$ & GROWTH & $(+)$ & & $\begin{array}{c}0.01560 \\
(2.72)^{* * *}\end{array}$ & $\begin{array}{c}0.01557 \\
(2.67)^{* * *}\end{array}$ & $\begin{array}{c}0.01568 \\
(2.68)^{* * *}\end{array}$ \\
\hline
\end{tabular}

\footnotetext{
${ }^{20}$ We have also classified the rival portfolios' two-day announcement-period abnormal returns by the number of delay announcements in each industry. We find that industries with more than two delay announcements experience a statistically significant average value loss of $0.30 \%$, whereas industries with one or two delay announcements experience an insignificant average value loss of $0.11 \%$.
} 
Table 5. (Continued)

\begin{tabular}{lcccccc}
\hline Variable & Variable & Pred. Equation (2) & Equation (3) & Equation (4) & Equation (5) \\
& Name & Sign & Model 1 & Model 2 & Model 3 & Model 4 \\
\hline $\begin{array}{l}\text { Industry R\&D } \\
\text { intensity }\end{array}$ & RDI & $(+)$ & & -0.00967 & -0.00967 & -0.00946 \\
$\begin{array}{l}\text { Delay information } \\
\text { dummy }\end{array}$ & TIME & \pm & & -0.00087 & -0.00090 & -0.00096 \\
$\begin{array}{l}\text { Product life } \\
\text { cycle dummy }\end{array}$ & PLC & $?$ & & $(-0.35)$ & $(-0.34)$ & $(-0.36)$ \\
$\begin{array}{l}\text { Contamination } \\
\text { dummy }\end{array}$ & CONTAM & $?$ & & & 0.00008 & -0.00003 \\
N & & & & & $(0.03)$ & $(-0.01)$ \\
Adjusted $R^{2}$ & & & 324 & & & 0.00075 \\
$F$-value & & & 0.021 & 0.082 & 0.079 & $(0.30)$ \\
\hline
\end{tabular}

Note: The dependent variable is the two-day announcement-period abnormal returns of industry rival portfolios. The announcer's abnormal return is measured over the interval beginning one day before the product delay announcement and ending on the day of the product delay announcement. The returns correlation is measured by the correlation of stock returns between the announcer and its competitors for the year preceding the announcement. Relative size is proxied by the announcer's sales divided by the median sales of rivals preceding the announcement. We then construct a dummy variable that takes a value of 1 if the relative size variable is greater than 1 and 0 otherwise. Relative free cash flow is measured by the announcer's cash flow ratio divided by the median cash flow ratio of the rivals, where cash flow ratio is defined as operating income before depreciation minus interest expense, taxes, preferred dividends, and common dividends, divided by the book value of total assets, for the fiscal year preceding the announcement. We then define a dummy variable that takes a value of 1 if relative free cash flow is greater than 1 and 0 otherwise. Relative financial leverage is measured by the announcer's debt ratio divided by the median debt ratio of the rivals, where debt ratio is defined as the book value of long-term debt to the book value of total assets for the fiscal year prior to the announcement. We then construct a dummy variable that takes a value of 1 if relative financial leverage is greater than 1 and 0 otherwise. The Herfindahl index is the sum of the squared fraction of industry sales by all firms in the industry for the fiscal year prior to the announcement. The industry growth rate is measured by the three-year average annual growth rates in sales prior to the delayed announcement. Industry R\&D intensity is defined as R\&D expenditures by all firms in the industry divided by industry net sales for the fiscal year prior to the announcement. The delay information dummy variable is equal to 1 if an estimate for the length of delay is given and 0 otherwise. The product life cycle dummy is equal to 1 if the product involved in the delay is computer hardware or software and 0 otherwise. A contamination dummy variable is included for those events with other contemporaneously announced information. The $t$-values in parentheses are computed with heteroskedasticity-consistent standard errors if tests reject homoskedasticity at the $10 \%$ of significance level (White, 1980). The number of observations varies across regressions because of data availability. "***" and "**" represent $1 \%$ and $5 \%$ significance levels respectively. 
delay in new product introduction. The finding is consistent with the earlier result that, for the sample as a whole, the information-signaling effect dominates the competitive effect. The result shows that the negative information spillover effect on industry rivals is greater when the announcement effect on the product delay firm is more negative. This evidence supports that the intra-industry effects of new product delays are more pronounced when the share price of the announcing firm is affected to a greater degree.

Model 2 shows that the rivals' share price response is still significantly positively related to the announcers' announcement-period abnormal returns when other potentially important variables are included. We also find that returns correlation has a significantly negative impact on the rivals' share price response. This result suggests that the negative prospects of the firm that announces product delay are more likely to be transmitted throughout the industry when the firm's performance is closely linked to its competitors.

Model 2 shows that the relative free-cash-flow variable also has a significantly negative impact on the rivals' share price response. Firms that delay new product introductions typically require additional funding to see through the development of the product. If they do not have enough internal generated funds, they might not be able to successfully introduce the product to the market. Therefore, industry rivals experience more positive economic impact when product delay firms have relatively low free cash flow.

Model 2 also shows that industry rivals' share price response is significantly negatively related to Herfindahl index, which is a proxy for the degree of industry concentration. Since the degree of industry concentration is negatively related to the degree of industry competition, our results suggest a positive relation between rivals' share price response and the degree of industry competition. The evidence is consistent with the notion that, in a highly competitive industry, customers have more choices of buying competing products and rivals are more likely to gain competitive advantage relative to the firms that announce delays in new product introductions. Therefore, in such industries, the rivals' share price response would be more favorable.

We also find in Model 2 that industry growth rate has a significantly positive impact on rivals' share price response. In a fast growing industry, firms that delay the introduction of new products are expected to experience lost sales, lower profits and a loss of competitive advantage, as customers have less established loyalty and are less likely to wait for a firm's product if the product introduction is delayed. Our results suggest that rivals in high 
growth industries will benefit more when a firm in the industry experiences a delay in new product introduction.

Finally, Model 2 shows that industry rivals' share price response is not significantly related to SIZE, LEV, RDI and TIME. The evidence suggests that relative firm size, relative financial leverage, industry technological opportunities and information on the expected length of delay are relatively unimportant in explaining the rivals' share price response.

Models 3 and 4 show that the above results are essentially unchanged after we have included the product life cycle dummy (PLC) and the contamination dummy (CONTAM), both of which are statistically insignificant. In summary, the following five variables are found to be consistently significant in explaining the rivals' share price response associated with new product delay announcements: the announcement effect on the announcing firm, the degree of relatedness of the announcing firm to the industry, the level of the product delay firm's free cash flow relative to that of its rivals, the degree of industry competition and the industry growth opportunities. That is, industry rivals' share price response is significantly positively related to the announcement effect on the product delay firm, the degree of industry competition and the industry growth opportunities, and is significantly negatively related to the degree of relatedness and the degree of relative free cash flow.

\section{Conclusion}

Hendricks and Singhal (1997) show that firms that announce delays in new product introductions generally experience a reduction in firm value. This paper extends the literature on product delays by examining the economic impact of delayed new product introductions on the industry rivals. The information-signaling effect predicts that the industry rivals should experience negative economic effect, whereas the competitive effect suggests that they should experience positive economic effect. We document that rival firms overall experience a significantly negative share price response. This evidence suggests that, for our sample as a whole, the information-signaling effect dominates the competitive effect.

We further classify the rivals' share price response by industry and find that about $60 \%$ of industries have negative response. Rivals in pharmaceuticals preparations, industrial organic chemicals and air transport industries experience the most statistically significantly unfavorable share price response. We also find that a product delay conveys more negative 
information about the competitors in the industries that are more likely to have product delays, which suggests that the effect of negative information transfer is greater than the competitive effect within these industries.

We also relate the rivals' share price response to a number of potentially important explanatory factors: the announcement effect on the product delay firm; the degree of relatedness of the product delay firm to the industry; the product delay firm's size, free cash flow and financial leverage relative to those of its rivals; the competitiveness, growth, and technological opportunities of the industry; and the information on the expected length of delay. We document that the rivals' share price response is significantly related to the announcement effect on the product delay firm, the degree of relatedness, the relative free cash flow, the degree of industry competition and the industry growth opportunities. Specifically, industry rivals' share price response is positively related to the announcement effect on the product delay firm, the degree of industry competition and the industry growth opportunities, and is negatively related to the degree of relatedness and the relative free cash flow.

\section{Acknowledgments}

The authors wish to thank seminar participants at the 2001 Financial Management Association Annual Meeting for helpful comments and suggestions. Shao-Chieh Lin and Guan-Chun Chou provided capable research assistance. Any remaining errors are the authors'. Sheng-Syan Chen acknowledges funding from National Science Council in Taiwan (NSC89-2416-H155-007).

\section{References}

Aharony, J and I Swary (1983). Contagion effects of bank failures: Evidence from capital markets. Journal of Business, 56, 305-322.

Ahmed, P, J Gardella and S Nanda (2002). Wealth effects of drug withdrawals on firms and their competitors. Financial Management, 31, 21-41.

Akhigbe, A, J Madura and A Whyte (1997). Intra-industry effects of bond rating adjustments. Journal of Financial Research, 20, 545-561.

Akhigbe, A and A Martin (2000). Information-signaling and competitive effects of foreign acquisitions in the US. Journal of Banking and Finance, 24, $1307-1321$.

Atiase, R (1985). Predisclosure information, firm capitalization and security price behavior around earnings announcements. Journal of Accounting Research, 23, $21-36$.

Baginski, S (1987). Intra-industry information transfers associated with management forecasts of earnings. Journal of Accounting Research, 25, 196-219. 
Barclay, M and C Smith (1995). The maturity structure of corporate debt. Journal of Finance, 50, 609-631.

Biggadike, R (1976). Entry Strategy and Performance. Cambridge, MA: Harvard University Press.

Bolton, P and D Scharfstein (1990). A theory of predation based on agency problems in financial contracting. American Economic Review, 80, 93-106.

Capron, L and N Pistre (2002). When do acquirers earn abnormal returns? Strategic Management Journal, 23, 781-794.

Chan, S, J Martin and J Kensinger (1990). Corporate research and development expenditures and share value. Journal of Financial Economics, 26, 255-276.

Chaney, P, T Devinney and R Winer (1991). The impact of new product introductions on the market value of firms. Journal of Business, 64, 573-610.

Chen, S and K Ho (1997). Market response to product-strategy and capitalexpenditure announcements in Singapore: Investment opportunities and free cash flow. Financial Management, 26, 82-88.

Chen, S, K Ho and K Ik (2005). The wealth effect of new product introductions on industry rivals. Journal of Business, 78, 969-996.

Chen, S, K Ho, K Ik and C Lee (2002). How does strategic competition affect firm values? A study of new product announcements. Financial Management, 31, $67-84$.

Chen, S, L Ho and Y Shih (2006). Intra-industry effects of corporate capital investment announcements. Financial Management, forthcoming.

Clark, K and T Fujimoto (1991). Product Development Performance. Cambridge, MA: Harvard Business School Press.

Comanor, W (1967). Market structure, product differentiation, and industrial research. Quarterly Journal of Economics, 81, 639-657.

Davis, D (1989). Beating the clock. Electronic Business, May 29, 21-29.

Denis, D (1994). Investment opportunities and the market reaction to equity offerings. Journal of Financial and Quantitative Analysis, 29, 159-177.

Dodd, P and J Warner (1983). On corporate governance: A study of proxy contexts. Journal of Financial Economics, 11, 401-438.

Eckbo, B (1983). Horizontal mergers, collusion and stockholder wealth. Journal of Financial Economics, 11, 241-273.

Eckel, C, D Eckel and V Singal (1997). Privatization and efficiency: Industry effects of the sale of British Airways. Journal of Financial Economics, 43, 275-298.

Erwin, G and J Miller (1998). The intra-industry effects of open market share repurchases: Contagion or competitive? Journal of Financial Research, 21, 389-406.

Fazzari, S, G Hubbard and B Petersen (1988). Finance constraints and corporate investment. Brookings Papers on Economic Activity, 1, 141-195.

Firth, M (1996). Dividend changes, abnormal returns and intra-industry firm valuations. Journal of Financial and Quantitative Analysis, 31, 189-211.

Foster, G (1981). Intra-industry information transfers associated with earnings releases. Journal of Accounting and Economics, 3, 201-232.

Guenther, D and A Rosman (1994). Difference between Compustat and CRSP SIC codes and related effects on research. Journal of Accounting and Economics, 18, 115-128. 
Hendricks, K and V Singhal (1997). Delays in new product introductions and the market value of the firm: The consequences of being late to the market. Management Science, 43, 422-436.

Hertzel, M (1991). The effects of stock repurchases on rival firms. Journal of Finance, 46, 707-716.

Hoshi, T, A Kashyap and D Scharfstein (1991). Corporate structure, liquidity, and investment: Evidence from Japanese panel data. Quarterly Journal of Economics, 106, 33-60.

Kabir, R, D Cantrijn and A Jeunink (1997). Takeover defenses, ownership structure and stock returns in the Netherlands: An empirical analysis. Strategic Management Journal, 18, 97-109.

Kahle, K and R Walkling (1996). The impact of industry classifications on financial research. Journal of Financial and Quantitative Analysis, 31, 309-335.

Kelm, K, V Narayanan and G Pinches (1995). Shareholder value creation during $\mathrm{R} \& \mathrm{D}$ innovation and commercialization stages. Academy of Management Journal, 38, 770-786.

Kovenock, D and G Philips (1997). Capital structure and product market behavior: An examination of plan exit and investment decisions. Review of Financial Studies, 10, 767-803.

Lang, L, E Ofek and R Stulz (1996). Leverage, investment, and firm growth. Journal of Financial Economics, 40, 3-29.

Lang, L and R Stulz (1992). Contagion and competitive intra-industry effects of bankruptcy announcements. Journal of Financial Economics, 32, 45-60.

Lang, L, R Stulz and R Walkling (1989). Managerial performance, Tobin's $q$, and the gains from successful takeovers. Journal of Financial Economics, 24, $315-335$.

Lang, L, R Stulz and R Walkling (1991). A test of the free cash flow hypothesis: The case of bidder returns. Journal of Financial Economics, 29, 315-335.

Lehn, K and A Poulsen (1989). Free cash flow and stockholder gains in going private transactions. Journal of Finance, 44, 771-787.

Mahajan, V, S Sharma and D Buzzell (1993). Assessing the impact of competitive entry on market expansion and incumbent sales. Journal of Marketing, 57, $39-52$.

Myers, S (1977). Determinants of corporate borrowing. Journal of Financial Economics, 5, 147-175.

Nevens, T, G Summe and B Uttal (1990). Commercializing technology: What the best companies do? Harvard Business Review, 68, 154-163.

Nixon, R, M Hitt, H Lee and E Jeong (2004). Market reactions to announcements of corporate downsizing actions and implementation strategies. Strategic Management Journal, 25, 1121-1129.

Ohmae, K (1985). Managing innovation and new products in key Japanese industries. Research Management, 28, 11-18.

Phillips, G (1995). Increased debt and industry product markets: An empirical analysis. Journal of Financial Economics, 37, 189-238.

Robinson, W and C Fornell (1985). The sources of market pioneer advantages in consumer goods industries. Journal of Marketing Research, 22, 297-304. 
Seth, A, K Song and R Pettit (2002). Value creation and destruction in cross-border acquisitions: An empirical analysis of foreign acquisitions of US firms. Strategic Management Journal, 23, 921-940.

Shen, W and A Cannella (2002). Will succession planning increases shareholder wealth? Evidence from investor reactions to relay CEO successions. Strategic Management Journal, 24, 191-198.

Slovin, M, M Sushka and Y Bendeck (1991). The intra-industry effects of goingprivate transactions. Journal of Finance, 46, 1537-1550.

Slovin, M, M Sushka and J Polonchek (1992). Informational externalities of seasoned equity issues. Journal of Financial Economics, 32, 87-101.

Song, M and R Walkling (2000). Abnormal returns to rivals of acquisition targets: A test of the "acquisition probability hypothesis". Journal of Financial Economic, $55,143-172$.

Stulz, R (1990). Managerial discretion and financing policies. Journal of Financial Economics, 26, 3-27.

Sundaram, A, T John and K John (1996). An empirical analysis of strategic competition and firm values: The case of $\mathrm{R} \& \mathrm{D}$ competition. Journal of Financial Economics, 40, 459-486.

Szewczyk, S (1992). The intra-industry transfer of information inferred from announcements of corporate security offerings. Journal of Finance, 47, $1935-1945$.

Urban, G, T Carter, S Gaskin and Z Mucha (1986). Market share rewards to pioneering brands: An empirical analysis and strategic implications. Management Science, 32, 645-659.

White, H (1980). A heteroskedasticity-consistent covariance matrix estimator and a direct test for heteroskedasticity. Econometrica, 48, 817-838.

Woolridge, R and J Snow (1990). Stock market reaction to strategic investment decisions. Strategic Management Journal, 11, 353-363.

Zantout, Z and G Tsetsekos (1994). The wealth effects of announcements of R\&D expenditure increases. Journal of Financial Research, 17, 205-216. 